\title{
Role of Liquid-Liquid Phase Transitions in Mechanism of Erythrocyte Protection During Cooling with CRIHBT-11 ${ }_{5}$ Cryopreservative Agent
}

Реферат: Методом поляризаційної мікроскопії та фріксації явища критичної опалесценції в концентраті еритроцитів 3 кріоконсервантом ЦНДІГПК-11, (розроблений у Центральному науково-дослідному інституті гематології та переливання крові (Росія)), який вміщує гліцерин, підчас охолодження встановлено наявність в системі критичного фразового перетворення (ФП) типу рідина-рідина за механізмом, що призводить до утворення дисперсної системи - висококонцентрованої емульсії. Ознак кристалізації в досліджуваній кріобіологічний системі не виявлено. Вивчалася фазова поведінка в циклі охолодження-нагрівання кріоконсерванта та надосаду. Проведена порівняльна якісна оцінка зміни об'єму кріоконсерванта та еритроконцентрату у процесі охолодження. Визначено механізм захисної дії кріоконсервуючого розчину. Встановлено схожість фрізико-хімічних процесів при охолодженні-нагріванні в цитоплазмі еритроцитів та клітин меристеми часнику (зародковій рослинній тканині) під час переходу до стану холодового анабіозу.

Ключові слова: фазові перетворення типу рідина-рідина, кристалізація, склування, дисперсні системи, кріоконсервування, кріоушкодження, кріопротектори, еритроцити, поляризаційна мікроскопія.

Abstract: The presence in the system of critical liquid-liquid phase transition (PT) by the mechanism, resulting in formation of dispersion system, namely high-concentrated emulsion, has been established here during cooling when using polarized light microscopy and fixation of critical opalescence phenomenon in erythrocyte concentrate with glycerol-containing cryopreservative agent, designed at the Central Research Institute of Haematology and Blood Transfusion (Russia) (CRIHBT-11 ${ }_{5}$ ). The studied cryobiological system displayed no signs of crystallization. A phase behaviour of cryopreservative and supernatant has been studied during cooling-warming cycle. Changes in the volume of cryopreservative and erythrocyte concentrate were comparatively and qualitatively evaluated during cooling. The mechanism of protective action of cryopreservation solution has been determined. The similarity between physical and chemical processes during cooling-warming of erythrocyte cytoplasm and garlic meristem cells (germinal plant tissue) when entering cold anabiosis has been established.

Key words: liquid-liquid phase transitions, crystallization, vitrification, dispersed systems, cryopreservation, cryoinjury, cryoprotectants, erythrocytes, polarized light microscopy.

Низькотемпературне консервування клітин крові та кісткового мозку $з$ метою клінічного застосування є одним із пріоритетних завдань кріобіології. Саме трансфузія кріоконсервованих еритроцитів була вперше застосована в практичній медицині [39].

Сьогодні в галузі кріобіології і кріомедицини найбільш поширеними з точки зору природи фазових перетворень (ФП) у кріобіологічних системах (підготовлений до кріоконсервування комплекс, який складається з біооб' єкта, фізичних, хімічних та інших засобів захисту) під час охолодження $є$ уявлення про кристалізацію - перетворення типу рідина-кристал (LCPT) $[10,18,32]$. Разом 3 тим 3 фізичної хімії розчинів відомо, що в них можливі два типи ФП - LCPT і ФП

Інститут проблем кріобіології і кріомедицини НАН України, м. Харків
Low-temperature preservation of blood and bone marrow cells for clinical application is among the priority tasks in cryobiology. Namely the transfusion of cryopreserved erythrocytes was first used in practical medicine [28].

To date, the idea of crystallization as the liquidcrystal phase transition (LCPT) is the most common in cryobiology and cryomedicine in terms of nature of phase transitions (PH) in cryobiological systems (that are a complex, including biological object, physical, chemical and other protective means, prepared for cryopreservation) during cooling $[43,32$, 14]. However, as is well known from physical chemistry of solutions, the two types of PT, namely LCPT and liquid-liquid phase transition (LLPT) are common in it $[30,33,3]$. Herewith, the initially

Institute for Problems of Cryobiology and Cryomedicine of the National Academy of Sciences of Ukraine, Kharkiv, Ukraine

\section{Address for correspondence:}

23, Pereyaslavska str., Kharkiv, Ukraine 61016;

tel.:+380 57373 7435, fax: +380 573735952

e-mail: a.khodko85@gmail.com

Received September, 10, 2018

Accepted August, 31, 2021 вул. Переяславська, 23, м. Харків, Україна 61016

тел.: (+38 057) 373-74-35, фракс: (+38 057) 373-59-52

Надійшла 10.09.2018

Прийнята до друку 31.08.2021 
рідина-рідина (LLPT) [16, 19, 26]. При цьому первинно однорідний розчин розпадається на дві або декілька рідких фаз, які відрізняються за хімічним складом. Такий тип ФП характерний для систем полімер-розчинник [16, 19]. Більшості полімерів із розгалуженим ланцюгом через стеричні (просторові) обмеження в розчиненому стані не властивий мікрофазний поділ - міцелоутворення. Ці системи поділяються за макрофазним механізмом з утворенням грубодисперсних систем - емульсій. За умов зміни параметрів стану згідно з теорією розчинів полімерів Флорі-Гаггінса більш висока ймовірність фазового поділу властива розчинам полімерів, ніж розчинам низькомолекулярних рідин. Це обумовлено меншою зміною ентропії змішування в полімерних розчинах в порівнянні 3 простими рідинами [33].

Сучасна фізика конденсованого стану інтенсивно вивчає так звану м'яку матерію: полімери, колоїди, розчини протеїнів, у тому числі цитоплазму. Взаємодія між частинками в таких системах описується складними анізотропними потенціалами, фазова поведінка яких за зміни параметрів стану набагато складніша, ніж у зріджених інертних газів. Фазова поведінка останніх добре описується за допомогою ізотропних ефективних потенціалів, зокрема потенціалом Леннарда-Джонса. Такий характер взаємодії також ускладнює і фазові діаграми, на яких можуть 3'явитися множинні кристалічні фази, водоподібні аномалії, переходи типу рідина-рідина та інші феномени [19].

B. Wowk [43] вказує на можливість фазового розпаду за спінодальним механізмом в деяких рідких системах, але безпідставно відзначає, що такі явища в кріобіології практично не розглядаються.

Процес кристалізації в розчинах може мати вторинний характер, тобто процесу нуклеації зародка кристалічної фази передує поділ розчину на аморфні фази $[1,16,42]$. Такий тип утворення зародків деякі автори називають «некласична нуклеація» [30].

Поділ за типом рідина-рідина в розчині термодинамічно більш імовірний, ніж рідина-кристал, оскільки вимагає лише флуктуації за концентрацією без тривимірної впорядкованості, необхідної для утворення кристалічної фази. Якщо швидкість формування кристалічного зародка (індукційний період) менша порівняно зі швидкістю зміни параметра стану, то кристалізація в кінцеві терміни експерименту може не відбутися, і система буде складатися тільки 3 аморфних фаз [16]. homogeneous solution decomposes into two or more liquid phases, differing by chemical composition. This type of PT is specific for polymer-solvent systems [30, 33]. Most polymers with a branched chain due to steric (spatial) limitations in dissolved state are not characterized by microphase separation, $i$. e. the micelle formation. These systems are separated by macrophase mechanism with formation of poor-dispersed systems: emulsions. According to Flory-Huggins solution theory, the polymer solutions demonstrate a higher probability of phase separation, than the low molecular weight liquids under state parameter alteration. This is due to less altered entropy of mixing in polymer solutions vs. ordinary liquids [18].

Modern condensed matter physics is intensively studying the so-called soft matter, i. e. polymers, colloids, protein solutions, including cytoplasm. The interaction between particles in these systems is described by complex anisotropic potentials, the phase behaviour of which is much more complicated when changing state parameters if compared with liquefied inert gases. The phase behaviour of the latter is well described by isotropic effective potentials, in particular the Lennard-Jones one. A complex nature of interaction makes the phase diagrams difficult as well, wherein the multiple crystal phases, water-like anomalies, liquid-liquid transitions, and other phenomena may appear [19].

V. Wowk [41] indicated a possible phase separation by spinodal mechanism in some liquid systems, but unreasonably stated these phenomena not to be usually considered in cryobiology.

Crystallization in solutions may be secondary, $i$. e. the crystalline phase nucleation is preceded by solution separation into amorphous phases $[4,30$, 38]. Some authors designated this type of nucleation as 'nonclassical' [11].

The liquid-liquid separation in the solution is thermodynamically more likely than the liquid-crystal one, because only concentration fluctuations without three-dimensional ordering, necessary for crystalline phase formation, are needed. If nucleation rate of crystalline nucleus formation (induction period) is lower than that of state parameter change, the crystallization may not occur at the end of experiment, and the system will consist of amorphous phases only [30].

It is difficult to distinguish between LLPT and LCPT if using the common in cryobiology methods of thermal analysis (dilatometry and differential scanning calorimetry (DSC)). Both these PT are firstorder ones, and therefore have thermal and volumetric effects $[17,34]$. The critical state, accompanying LLPT by nucleation and growth mechanism can not be recorded with DSC [2]. 
Поширеними в кріобіології методами термічного аналізу (дилатометрією і диференціальною сканувальною калориметрією (ДСК)) складно розрізнити LLPT і LCPT. Вказані ФП відносяться до першого роду i, отже, мають тепловий й об'ємний ефекти $[9,20]$. Критичний стан, що супроводжує LLPT за механізмом нуклеації-росту, не може бути зареєстрований ДСК [25].

Для ефективного якісного аналізу системи на предмет визначення типу ФП використовують оптичні методи [7]. На практиці термічні й оптичні методи аналізу доповнюють один одного. Проведення рентгеноструктурного аналізу, який теж $є$ оптичним, потребує багато часу [6], а реєстрація цим методом метастабільних, існуючих обмежений час фаз може бути утрудненою.

У результаті спостереження за критичною опалесценцією під час охолодження живих рослинних тканин і виділених з них рідин був виявлений LLPT [36]. Таким самим ФП деякі дослідники пояснюють існування в цитоплазмі рослинних і тваринних клітин безмембранних органел $[2,24,27-29,34,35,37]$. Значну допомогу у вивченні фазового стану системи може надати метод поляризаційної мікроскопії, заснований на здатності впорядкованої фази обертати площину поляризації світла завдяки властивій для неї оптичній анізотропії [31].

Ф.Р. Віноград-Финкель та співавт. [6] методом рентгеноструктурного аналізу показала значне переважання аморфної фази в еритроцитарній масі, яка була охолоджена 3 додаванням кріоконсерванта на основі гліцерину.

Мета роботи - ідентифікування типів фазових перетворень під час охолодження нативного еритроконцентрату донорської крові, еритроконцентрату 3 додаванням кріоконсерванта ЦНДІГПК- $11_{5}$, а також визначення ролі фазових перетворень у механізмах кріопротективної дії.

\section{Матеріали та методи}

У роботі використовували метод низькотемпературного консервування еритроцитів 3 кріоконсервантом ЦНДІГПК-11 ${ }_{5}$ (розроблений у Центральному науково-дослідному інституті гематології та переливання крові (Росія)) [8] на етапі еквілібрації клітин з кріоконсервантом, охолодження і відігрівання.

Експерименти виконували на п'яти зразках крові A (II) $\mathrm{Rh}^{+}$, отриманих від донорів-чоловіків. Зразки крові було надано «Харківським центром служби крові» (Україна).

Кріоконсервант ЦНДІГПК-11, має наступний склад: маніт - 40,0 г; натрію хлорид - 7,0 г
For efficient qualitative analysis of the system one uses the optical methods to determine the PT type [15]. In practice, thermal and optical methods of analysis are complementary. The X-ray diffraction analysis, being an optical technique as well, is timeconsuming [39], and such recording of metastable phases, existing for limited time, would be difficult.

When observing a critical opalescence during cooling of living plant tissues and isolated from them liquids, the LLPT was detected [23]. By this transition, some researchers explained the existence of membraneless organelles in plant and animal cell cytoplasm $[1,5,6,9,10,19,20,25]$. Polarized light microscopy, based on the ability of ordered phase to rotate the plane of light polarization due to its inherent optical anisotropy may be very helpful in studying the phase state of the system [13].

F.R. Vinograd-Finkel et al. [39] using X-ray diffraction analysis showed a significant predominance of amorphous phase in erythrocyte mass, cooled with a supplement of glycerol-based cryopreservative.

The research aim was to identify the types of phase transition during cooling of native erythrocyte concentrate derived from donated blood, supplemented with cryopreservative agent, designed at the Central Research Institute of Haematology and Blood Transfusion (Russia) (CRIHBT-11 5 ), as well as to determine the role of phase transitions in cryoprotective mechanisms.

\section{Materials and methods}

Here, we used the method of low-temperature preservation of erythrocytes using the CRIHBT- $11_{5}$ cryopreservative [16] at the stages of cell equilibration with cryopreservative, cooling and heating.

Experiments were performed in five specimens of $\mathrm{A}$ (II) $\mathrm{Rh}^{+}$blood type, procured from man donors. Blood samples were provided by the Kharkiv Blood Service Center (Ukraine).

The CRIHBT- $11_{5}$ cryopreservative has the following composition: $40.0 \mathrm{~g}$ mannitol; $7.0 \mathrm{~g}$ sodium chloride or $3.0 \mathrm{~g} \mathrm{Na}_{2}$ EDTA; $0.3 \mathrm{~g}$ disubstituted sodium phosphate; $400 \mathrm{ml}$ glycerol; water for injections up to $1,000 \mathrm{ml}$.

Erythrocyte concentrate was obtained by a 10-min centrifugation of donated blood at $1,900 \mathrm{~g}$. A sample of 2-3 ml volume was placed into a test tube, gradually supplemented with a cryopreservative in 1:1 ratio during stirring [16].

After 10-min equilibration, a cell suspension was centrifuged at $1,900 \mathrm{~g}$ for $10 \mathrm{~min}$ under constant stirring. The supernatant was then taken from the system and placed into another container.

A $25 \mu \mathrm{l}$ drop of precipitate, being a highly concentrated cell suspension, was applied to the silica 
або ЕДТА $\mathrm{Na}_{2}-3,0$ г; натрію фосфат двозаміщений - 0,3 г; гліцерин - 400 мл; вода для ін'єкцій до 1000,0 мл.

Еритроконцентрат отримували 10-хвилинним центрифугуванням при $1900 \mathrm{~g}$ донорської крові. Пробу об'ємом 2-3 мл поміщали в пробірку, в яку поступово при помішуванні додавали кріоконсервант у співвідношенні 1:1 [8].

Клітинну завісь після 10-хвилинної еквілібрації за умов постійного перемішування центрифугували при $1900 \mathrm{~g}$ протягом 10 хв. Після цього з системи відбирали надосад в іншу ємність.

Краплю осаду об'ємом 25 мкл, яка є висококонцентрованою клітинною зависсю, наносили на поверхню чашки Петрі (діаметром 60 мм) із силікатного скла і розподіляли носиком піпетки для зменшення товщини шару.

Пробу охолоджували обдуванням струменем пари рідкого азоту $\left(\mathrm{LN}_{2}\right)$ з горловини посудини Дьюара, яку розміщали на відстані 30-35 мм, а також наливанням рідкого азоту на досліджувану систему безпосередньо під об'єктивом мікроскопа.

Мікроскопію в поляризованому світлі проводили на поляризаційному мікроскопі «МІН-8» («ЛОМО», Росія).

Метод визначення фазового стану системи заснований на властивості оптичної активності, притаманній більшості кристалічних анізотропних фаз, зокрема гексагональному льоду. Найбільш вираженим проявом цієї властивості є здатність речовини обертати площину поляризації світла, яке проходить [4].

У схрещеному стані поляризатора й аналізатора світло практично не проходить через оптичну систему мікроскопа. Якщо між ними помістити оптично анізотропне (наприклад, кристалічне) тіло, то відновиться проходження частини світлового потоку через систему. Ці об'єкти будуть світитися на фоні темного поля мікроскопа. Для деяких полімерів й аморфних тіл у напруженому стані також характерна оптична анізотропія, яку необхідно враховувати під час проведення досліджень [4].

Фіксацію мікроскопічного зображення проводили цифровою фотографічної камерою «Sony DSC W-55» («Sony Corp», Китай).

Якісну порівняльну оцінку зміни об'єму кріобіологічних систем у момент ФП проводили з охолодженням досліджуваного зразка в скляних капілярах для визначення гематокриту довжиною 75 мм і внутрішнім діаметром 1 мм («Мінімед», Росія). Механічне руйнування капіляра свідчило про суттєве збільшення об'єму системи під час $Ф П$. glass Petri dish (60 mm diameter) surface and spread with pipette tip to reduce the layer thickness.

The specimen was cooled by blowing with a jet of liquid nitrogen $\left(\mathrm{LN}_{2}\right)$ vapour from the Dewar vessel neck, placed at a distance of 30-35 mm, as well as by pouring of liquid nitrogen on the test system directly under objective of microscope.

Polarized light microscopy was performed using 'MIN-8' microscope (LOMO, Russia).

The method for system phase state determination is based on the property of optical activity inherent in most crystalline anisotropic phases, in particular, hexagonal ice. This property is mostly pronounced in the substance ability to rotate the plane of polarization of transmitted light [37].

In a crossed state of polarizer and analyzer, the light does not virtually pass through the microscope optical system. If an optically anisotropic (e. g. crystalline) body is placed between them, a part of light flux through the system will resume. These objects will glow against the dark field of microscope. Some polymers and amorphous bodies in a stressed state are also characterized by optical anisotropy, which should be taken into account in research performance [37].

Microscopic image was taken with Sony DSC W-55 digital photo camera (Sony Corp, China).

A change in the volume of cryobiological systems during PT was qualitatively and comparatively assessed by test sample cooling in $75 \mathrm{~mm}$ glass hematocrit tubes with $1 \mathrm{~mm}$ inner diameter (Minimed, Russia). Mechanical destruction of the tube indicated a significant increase in the system volume during PT.

The PT temperature was determined in during cooling the cryovial (SPL Life Sciences, Korea) filled with a solution or cell suspension at $3^{\circ} \mathrm{C} / \mathrm{min}$ rate using a programmable freezer ZP-10 (Special Designing and Technical Bureau with Experimental Unit at the Institute for Problems of Cryobiology and Cryomedicine of the NAS of Ukraine).

\section{Results and discussion}

A drop of CRIHBT- $11_{5}$, cooled on Petri dish surface with liquid nitrogen vapours, showed the appearance of dendritic structures, not transmitting light at crossed position of polarizers (Fig. 1). This effect indicated the absence of crystalline phases, ice in particular, in the system. After pouring liquid nitrogen directly over a drop of the solution (to achieve a higher cooling rate), the light passage was also absent both in cooling and warming.

The cooling of cryopreservative agent in liquid nitrogen vapours or glass tube immersion directly into liquid nitrogen $(3-4 \mathrm{ml})$ showed the PT, as a result of which a milky-white product with gel- 
Температуру фазового перетворення визначали під час охолодженя кріопробірки («SPL Life Sciences», Корея) з розчином або клітинною суспензією зі швидкістю $3{ }^{\circ} \mathrm{C} /$ хв за допомогою програмного заморожувача ЗП-10 (СКТБ з ДВ ІПКіК НАН України).

\section{Результати та обговорення}

У краплі кріоконсерванта ЦНДІГПК- $11_{5}$, яку охолоджували на поверхні чашки Петрі парами рідкого азоту, спостерігалася поява дендритних структур, які в схрещеному положенні поляризаторів не пропускали світло (рис. 1). Даний ефект вказував на відсутність у системі кристалічних фаз, зокрема льоду. Після наливання рідкого азоту безпосередньо на краплю розчину (для досягнення більш високої швидкісті охолодження) проходження світла також було відсутнє як під час охолодження, так й відігрівання.

Під час охолодження кріоконсерванта в парах рідкого азоту або зануренні скляної пробірки безпосередньо в рідкий азот (3-4 мл) спостерігалося ФП, у результаті якого утворювався молочно-білий продукт із гелеоподібною консистенцією, i набував твердого стану при температурі рідкого азоту. Важливо відзначити, що ФП розчину не призводить до механічного руйнування пробірки, яке в більшості випадків спостерігається при заморожуванні води в аналогічних умовах. Під час відігрівання отриманий продукт спливав на поверхню власного розплаву, що вказує на його меншу щільність, тобто на збільшення об'єму системи при ФП.

Описані факти дозволяють зробити наступний висновок: в кріоконсерванті ЦНДІГПК- $11_{5}$, що досліджувався в розчині молекулярної дисперсності (істинному розчині), реалізовувався LLPT, у результаті якого утворювалася висококонцентрована емульсія - псевдогель [7].

Дендритна модульована структура емульсії (рис. 1) підтверджує спінодальний механізм фазового розпаду розчину. Структури 3 регулярним чергуванням ділянок високої та низької щільності забезпечують мінімальну суму хімічної вільної енергії та енергії внутрішніх механічних напружень у системі [17]. Впорядкованість системи $€$ проявом процесу самоорганізації, в результаті якого утворюються протяжні розгалужені структурні елементи, орієнтовані в напрямку максимальних компонент тензора зовнішнього механічного поля. Подібною структурною будовою пояснюється пластичність деяких аморфних сплавів, які за своєю природою є твердими розчинами [11]

Пробу еритроконцентрату донорської крові об'ємом 2-3 мл змішували 3 кріоконсервантом

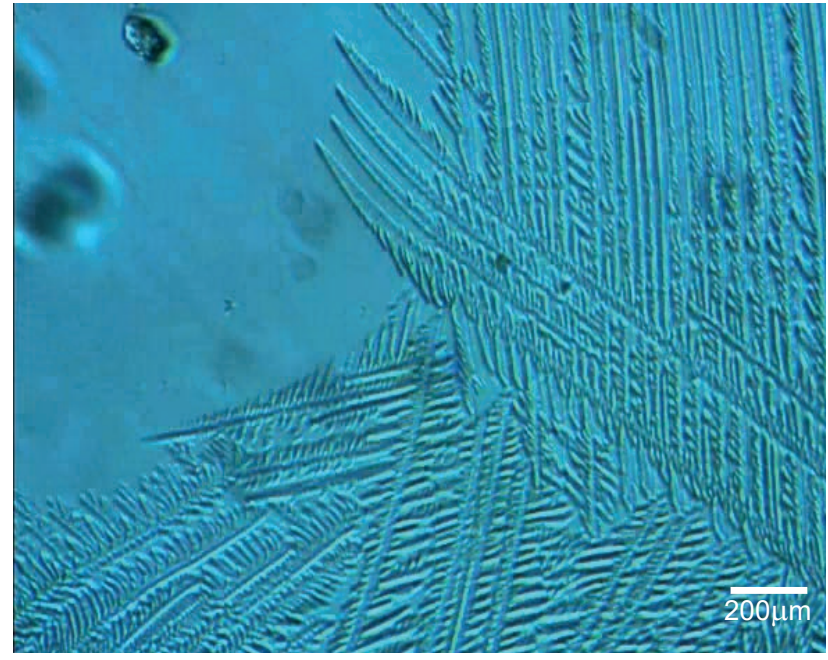

Рис. 1. Фазове перетворення у розчині кріоконсерванта ЦНДІГПК-11.

Fig. 1. Phase transition in CRIHBT-11, solution.

like consistency was formed, becoming solid at liquid nitrogen temperature. Noteworthy, that the solution PT entailed no mechanical destruction of the tube, mostly observed during water freezing under similar conditions. During warming, the obtained product floated on surface of its own melt, thereby indicating its lower density, i. e. an increased volume of the system during PT.

The above facts enable drawing the following conclusion: in cryopreservative agent CRIHBT- $11_{5}$, studied in molecular dispersion solution (true solution), there was realized the LLPT, as a result of which the highly concentrated emulsion, i. e. pseudogel was formed [15].

Dendritic modulated structure of the emulsion (Fig. 1) confirmed the spinodal decomposition mechanism of the solution. Structures with regular alternation of high and low density areas provided a minimum amount of chemical free energy and that of internal mechanical stresses in the system [31]. Its regularity was a manifestation of self-organization, as a result of which the long branched structural elements (microbands, shear bands), oriented towards the maximum components of the external mechanical field tensor, were formed. Such a structure explained the plasticity of some amorphous alloys, being solid solutions by nature [42].

A specimen of donated blood erythrocyte concentrate of 2-3 ml volume was mixed with CRIHBT- $11_{5}$ cryopreservative and centrifuged. After that, the system was separated into supernatant and erythrocyte concentrate. When a supernatant drop of $25 \mu \mathrm{l}$ volume was cooled in liquid nitrogen vapours, the translucence of dendritic structures was observed in crossed polarizers, that implied the crystallization (Fig. 2). 


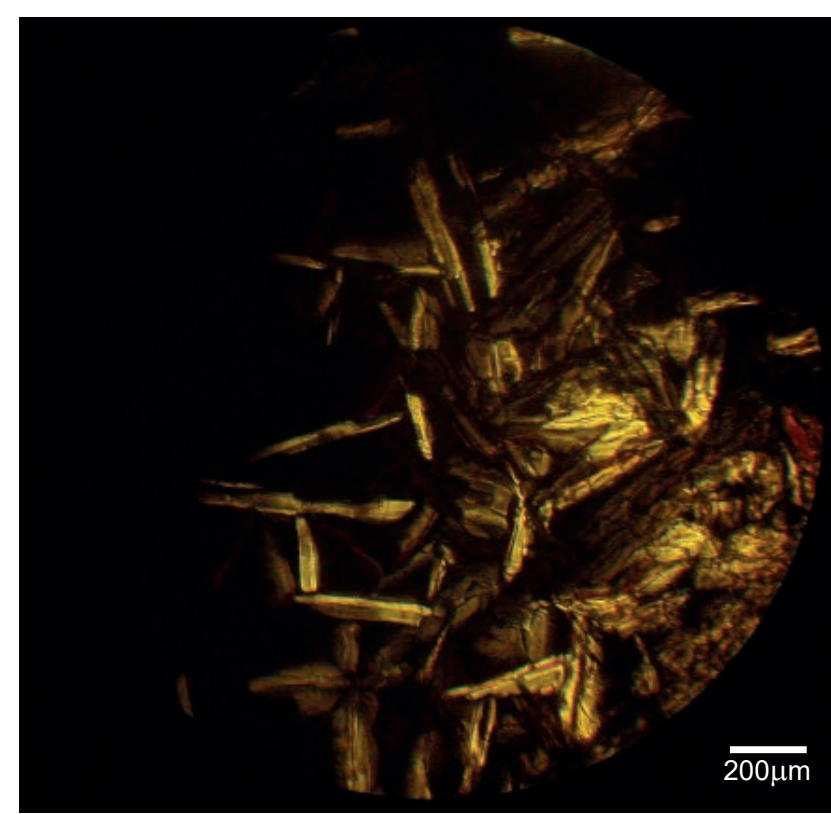

Рис. 2. Просвічування у схрещених поляризаторах льоду в надосаді.

Fig. 2. Translucence in crossed polarizers of ice in supernatant.

ЦНДІГПК- $11_{5}$ і центрифугували. Після цього систему поділяли на надосадову рідину і еритроконцентрат.

Під час охолодження парами рідкого азоту краплі надосадової рідини об'ємом 25 мкл у схрещених поляризаторах спостерігалося просвічування дендритних структур, що свідчить про процес кристалізації (рис. 2).

В еритроконцентраті, обробленому кріоконсервантом і охолодженому в аналогічних умовах, під час ФП утворювалися темні зони, характерні для процесу критичної опалесценції $[7,25]$ (рис. 3,4$).$ У схрещених поляризаторах ці зони не просвічувалися як у процесі охолодження, так і відігрівання, що свідчило про відсутність оптично активної фази у досліджуваному зразку. Після нагрівання зразка до кімнатної температури ознак гемолізу, зокрема, ефекту «лакової крові», не було виявлено.

Спостережувані ефекти вказують на наявність у системі критичного LLPT, який реалізується за механізмом нуклеації-росту зародків [5]. Критичний стан характеризується різким збільшенням флуктуацій параметра порядку, яким у випадку розчинів $є$ концентрація [38]. Флуктуації концентрації навколо критичної точки різко посилюють розсіювання світла системою, індикатриса якого різко витягнута в бік джерела збуджувальго світла [21].

Температура фазового перетворення в надосадової рідини відповідала $-9^{\circ} \mathrm{C}$, а в еритроконцентраті складала $-12^{\circ} \mathrm{C}$.
In the erythrocyte concentrate, processed with cryopreservative agent and cooled under similar conditions, the dark zones specific for critical opalescence were formed during PT $[2,15]$ (Figs. 3, 4). In crossed polarizers, these zones were not translucent both during cooling and warming, testifying thereby to the absence of optically active phase in the studied sample. After sample's warming up to room temperature, no signs of hemolysis, "laked blood' effect in particular, were detected.

The observed effects indicated the critical LLPT presence in the system, implemented via nucleation and growth mechanism [40]. The critical state was characterized by a sharp increase in fluctuations of order parameter, which in case of solutions was the concentration [26]. Concentration fluctuations near critical point sharply enhanced the light scattering by the system, the indicatrix of which was sharply extended towards the source of exciting light [12].

Temperature of phase transition in supernatant liquid and erythrocyte concentrate was -9 and $-12^{\circ} \mathrm{C}$, respectively.

The CRIHBT- $11_{5}$ - treated erythrocyte concentrate was cooled by liquid nitrogen pouring directly onto the test sample, that was a model of its immersion into liquid nitrogen [16]. In this case, no light passage in crossed position of polarizers was observed, thereby implying no ordered phase in the system, similar to crystalline one.

Basic concepts of crystallization evidence that if under relatively slow change of state parameter (temperature) no crystallization is realized in the system, it is less likely expected under more rapid cooling. First, the supercooling increases the formation frequency and growth rate of critical size

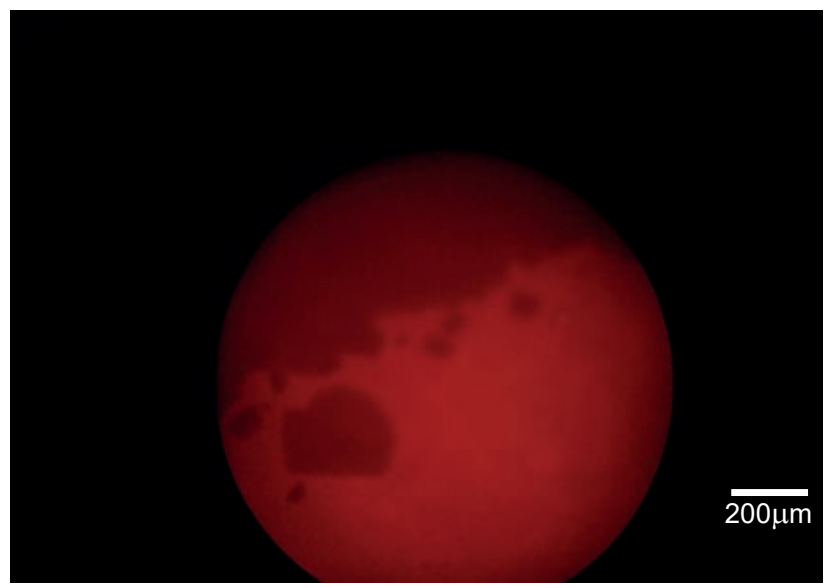

Рис. 3. Критичне фазове перетворення у зразку еритроконцентрату з кріоконсервантом ЦНДІГПК-11, під час охолодження.

Fig. 3. Critical phase transition in erythrocyte concentrate specimen with CRIHBT- $11_{5}$ during cooling. 
Еритроконцентрат, оброблений кріоконсервантом, охолоджували шляхом наливання рідкого азоту безпосередньо на досліджуваний зразок, що є моделлю його занурення в рідкий азот [8]. У цьому випадку також не спостерігалося проходження світла в схрещеному положенні поляризаторів, що вказувало на відсутність у системі впорядкованої фази, подібної до кристалічної.

I3 загальних уявлень про процеси кристалізації випливає, якщо кристалізація в системі не реалізується за умов відносно повільної зміни параметра стану (температури), то їі менш імовірно очікувати за більш швидкого охолодження. Переохолодження спочатку збільшує частоту формування і швидкість росту зародків критичного розміру кристалічної фази, а потім різко знижує їх внаслідок уповільнення трансляційної молекулярної рухливості та збільшення в'язкості системи $[3,26]$. Саме з цієї причини формуються численні системи, які здатні до склування. Вони у процесі охолодження розчинів переходять із термодинамічно стабільного рідкого в метастабільний твердий аморфний стан. Скло відноситься до так званих неергодичних систем. Властивості скла визначаються не тільки зовнішніми параметрами стану (температура, тиск), але й термобаричною передісторією його формування [3, 41]. Даний факт важливо враховувати під час кріоконсервуванні біооб'єктів.

Звернемо увагу, що клітини крові до центрифугування представляють у цій системі дисперсну фазу, знаходяться порівняно в малій концентрації в дисперсійному середовищі (надосад). Така фаза здатна кристалізуватися під час охолодження. Як було показано вище, у висококонцентрованій клітинній суспензії дисперсійне середовище вироджується в тонкі прошарки між клітинами. Фазова поведінка речовини в консолідованому i диспергованому стані може сильно різнитися внаслідок переважання поверхнево розташованих молекул, які інакше взаємодіють з навкружними сторонніми молекулами, ніж молекули в глибині фази [7]. Речовини у міжфазному просторі мають властивості й особливості, відмінні від таких в об'ємних фазах [12]. Саме цей фактор найбільш імовірно пояснює відсутність процесу кристалізації в концентрованій зависі еритроцитів. Добре відомо, що М. Фарадей припускав існування на поверхні льоду псевдорідинного шару води [13]. Імовірність утворення шляхом гомогенної нуклеації зародка критичного розміру нової фази в малорозмірних об'єктах також знижується.

Відзначимо, що цитоплазма клітини пронизана цитоскелетом і розділена внутрішніми мемб-

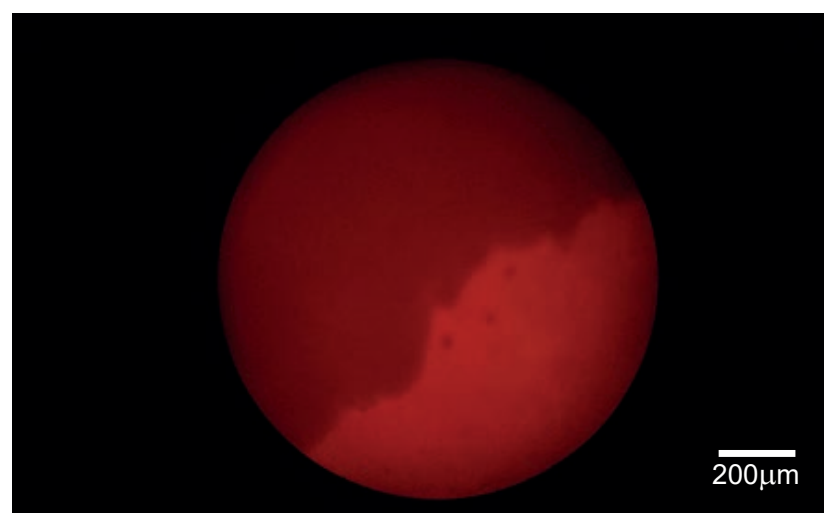

Рис. 4. Критичне фазове перетворення у зразку еритроконцентрату 3 кріоконсервантом ЦНДІГПК-11, під час охолодження (паралельний експеримент).

Fig. 4. Critical phase transition in erythrocyte concentrate specimen with CRIHBT-11, during cooling (parallel experiment).

nuclei of crystalline phase, and then sharply reduces them due to slowing down the translational molecular mobility and augmenting system viscosity $[3,7$,$] . It is very due to this reason that nume-$ rous systems capable of vitrification are formed. They pass from a thermodynamically stable liquid state to metastabe solid amorphous one during solutions' cooling. Glass belongs to the so-called nonergodic systems. The glass properties are determined not only by external parameters of the state (temperature, pressure) but thermobaric prehistory of its formation as well $[7,36]$. This fact should be considered when cryopreserving biological objects.

Notably, that blood cells prior to centrifugation represent a dispersed phase in this system, being relatively low concentrated in dispersion medium (supernatant). This phase is able to crystallize during cooling. As shown above, in a highly concentrated cell suspension the dispersion medium degenerates into thin layers between cells. Phase behaviour of the substance in consolidated and dispersed states may differ greatly due to the predominance of superficial molecules, that interact differently with surrounding outside molecules than those being deep in phase [15]. Substances in interfacial region have properties and features different from those in volumetric phases [21]. Namely this factor most likely explains the crystallization absence in concentrated suspension of erythrocytes. It is well known that M. Faraday assumed the existence of a quasi-liquid water layer on ice surface [24]. The probability of new phase critical nucleus formation in small-sized objects via homogeneous nucleation is also reduced.

The cell cytoplasm is noteworthy to be pierced with cytoskeleton and separated by inner membranes into compartments, being therefore a kind of dispersion system as well [35]. 
ранами на компартменти, внаслідок цього вона $€$ також своєрідною дисперсною системою [40].

Відомо, що розпад рідкого розчину може протікати за двома механізмами - нуклеації-росту зародків і спінодальним [5]. В останньому випадку ступінь дисперсності нової фази нижче, i, відповідно, підвищується можливість кристалізації через більшу ймовірність утворення шляхом гомогенної нуклеації зародка кристалу критичного розміру. Саме цим можливо пояснити дендритну структуру кристалічних фаз, яка характерна для спінодального механізму розпаду рідких розчинів (див. рис. 2) [5].

У роботі І.О. Некоз та співавт. [15] для зменшення оптичної щільності системи використовували сильно розбавлені зависі еритроцитів, що полегшувало візуальне спостереження за процесами. Фазова поведінка при зміні параметрів стану в розбавлених і концентрованих дисперсних системах, навіть при однаковому хімічному складі, може розрізнятися. Екстраполяція результатів, отриманих на низькоконцентрованих модельних системах, на більш концентровані реальні кріобіологічні системи може виявитися не коректною.

3 метою поліпшення візуалізації процесу фазового переходу краплю еритроконцентрату, яку наносили на поверхню скла, частково видаляли фільтрувальним папером. У цьому випадку товщина шару суспензії i, відповідно, іiі оптична щільність зменшувалися при збереженні високої клітинної концентрації, що дозволяло більш детально спостерігати за етапами ФП. У такій системі стає помітним хаотичне переміщення клітин, обумовлене конвективними потоками та броунівським рухом. На рис. 5, А проілюстровано виникнення дендритних структур, характерних для етапу спінодального розпаду розчину при LLPT, на рис. 5, В відображено наступну стадію процесу розпаду, яка реалізується за механізмом нуклеації-росту зародків. Цей етап, як і в повношаровому зразку концентрату еритроцитів, супроводжувався різким збільшенням розсіювання світла - критичною опалесценцією. У схрещеному положенні поляризаторів не спостерігалося проходження світла, що вказує на відсутність у системі впорядкованої кристалічної фази. В зразках більшої товщини стадія спінодального розпаду може бути або відсутньою, або не спостерігатися через їх значну оптичну щільність.

Фазова поведінка при охолодженні краплі еритроконцентрату і тонкошарової модельної системи в даному випадку якісно подібна, однак перенесення результатів, одержаних на тонкошаровому препараті на реальну сис-
It is of common knowledge that liquid solution may decompose via two mechanisms, namely nucleation and growth and spinodal ones [40]. In the latter case, the dispersion degree of new phase is lower, and hence the possibility of crystallization increases due to the greater probability of critical nucleus formation via homogeneous nucleation. This explains a dendritic structure of crystalline phases, being specific for spinodal decomposition mechanism in liquid solutions (see Fig. 2) [40].

I.O. Nekoz et al. [29] have used highly diluted erythrocyte suspensions in order to reduce an optical density of the system, thereby facilitating visual observation of processes. The phase behaviour when changing the state parameters in diluted and concentrated dispersed systems, even with the same chemical composition, may be different. Extrapolating the results obtained in low-concentrated model systems to more concentrated real cryobiological systems may be incorrect.

In order to improve the phase transition visualization, a drop of erythrocyte concentrate, applied to glass surface, was partially removed with filter paper. In this case, the thickness of suspension layer and, consequently, its optical density decreased while maintaining a high cell concentration, ensuring thereby more detailed observation of PT stages. In such a system, a chaotic movement of cells due to convective flows and Brownian motion became noticeable. The Fig. 5A illustrated the occurrence of dendritic structures specific for spinodal decomposition in LLPT. The Fig. 5B showed the next stage of decomposition, implementing via nucleation and growth mechanism. This stage was accompanied by a sharp increase in light scattering, $i$. e. critical opalescence, just as in a full-layer sample of erythrocyte concentrate. When the polarizers were in the crossed position, no light transmission was obser-
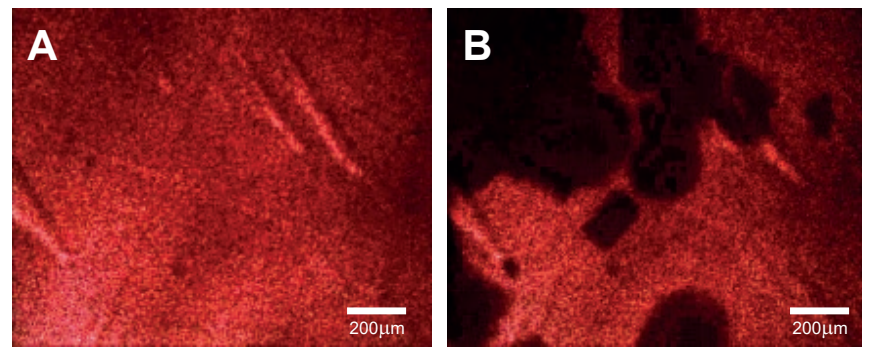

Рис. 5. Критичне фразове перетворення у тонкому шарі еритроконцентрату з кріоконсервантом ЦНДІГПК-11, при охолодженні парами $\mathrm{LN}_{2}$ : $\mathbf{A}$ - стадія розпаду розчину за спінодальним механізмом; В - наступна стадія процесу розпаду розчину за механізмом нуклеації-росту зародків.

Fig. 5. Critical phase transition in thin layer of erythrocyte concentrate with CRIHBT-11, under cooling with $\mathrm{LN}_{2}$ vapours: A is spinodal decomposition mechanism; $\mathbf{B}$ is nucleation and growth decomposition mechanism. 
тему, може бути некоректним. Контакт 3 фільтрувальним папером може порушувати співвідношення між дисперсною фазою та дисперсійним середовищем у клітинній завісі.

У роботі О.Т. Ходько [22] було показано, що причиною гемолізу при охолодженні концентрату донорських еритроцитів без додавання кріоконсерванта $€$ LLPT, оскільки LCPT під час охолодження такої системи не реєструвався.

3 викладеного вище випливає, що фазова поведінка у процесі охолодження як нативного, так i модифікованого додаванням кріоконсерванта концентрату еритроцитів якісно подібна. Кінцевий результат процесу охолодження-нагрівання клітинної зависі, який виражається в збереженні цілісності клітин тільки за присутності в системі кріоконсерванта і залежить від кількісних характеристик ефектів ФП.

Для порівняльної оцінки зміни об'єму систем у бік збільшення при ФП експериментальні зразки поміщали в скляні капіляри i охолоджували в пенопластовій ванні, розміщений на поверхні рідкого азоту. На наступному етапі досліджували концентрат нативних еритроцитів, його гемолізат, отриманий шляхом попереднього заморожування, і концентрат еритроцитів 3 додаванням кріоконсерванта.

Механічне руйнування капілярів внаслідок збільшення об'єму системи при ФП спостерігалося тільки у зразках, що не містили кріоконсерванта. Капіляри, які були заповнені попередньо гемолізованим еритроконцентратом, також руйнувалися під час охолодження (рис. 6, А). Це вказує на ідентичність фазової поведінки цитоплазми еритроцитів при охолодженні як цитоплазми всередині клітин, так й у вільному стані.

Капіляри, заповнені кріконсервуальним розчином ЦНДІГПК- $11_{5}$ у вільному стані, не руйнувалися у процесі охолодження (рис. 6, В).

За сукупністю одержаних результатів можна дійти висновку, що головною причиною гемолізу еритроцитів є збільшення об'єму їх цитоплазми під час охолодження внаслідок реалізації LLPT.

Захисна по відношенню до еритроцитів дія кріоконсерванта полягає в зменшенні ступеня збільшення об'єму при ФП їх цитоплазми, хімічно модифікованої шляхом додавання кріоконсервувального розчину. ved, thus indicating the absence of ordered crystalline phase in the system. In thicker specimens, the stage of spinodal decomposition may be neither present nor observed due to their significant optical density.

The phase behaviour when cooling a drop of erythrocyte concentrate and a thin-layer model system is here qualitatively similar, but it may be incorrect to translate the results obtained in a thin-layer preparation onto the real system. Contact with filter paper can disrupt the relationship between dispersed phase and dispersion medium in cell suspension.

The own investigations showed the hemolysis during donor erythrocyte concentrate cooling with no cryopreservative supplement to result from the LLPT, since no LCPT was recorded during such a system cooling [22].

Hence followed, that the phase behaviour during cooling of both native erythrocyte concentrate and the one modified with cryopreservative supplement was qualitatively similar. The final result of cooling-warming of cell suspension, manifested in cell integrity preservation only with a cryopreservative agent presence in the system, depended on quantitative characteristics of PT effects.

In order to comparatively assess a change in system volume towards increase during PT, the experimental specimens were placed into glass tubes and cooled in a foam bath placed on surface of liquid nitrogen. The next step was to investigate the
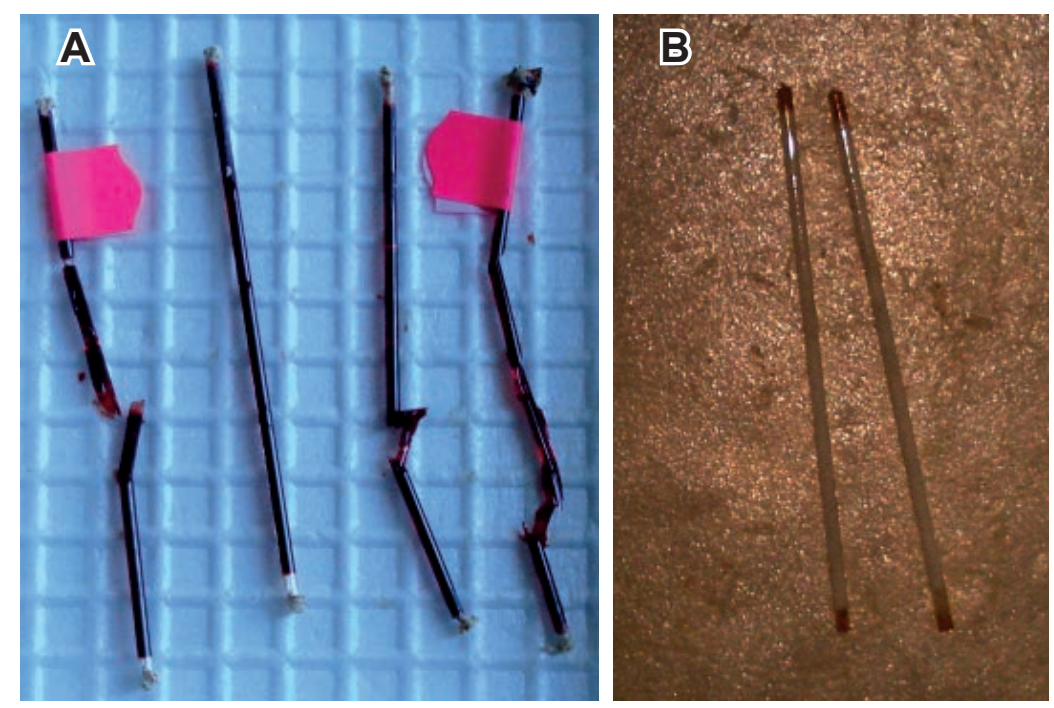

Рис. 6. Руйнування скляних капілярів протягом процесу охолодження-нагрівання (А). Капіляри зі стікерами заповнені гемолізованим ерітроконцентратом, а без стікера - нативним еритроконцентратом; В - відсутність процесу руйнування капілярів з розчином ЦНДІГПК-11, після охолодження.

Fig. 6. Destruction of glass tubes during cooling-warming (A). Tubes with stickers are filled with hemolyzed erythrocyte concentrate, and those without sticker are filled with native one; B is no destroyed tubes with CRIHBT-11, ${ }_{5}$ solution after cooling. 
Відомо, що LLPT $\epsilon$ зворотним процесом по відношенню до змішування [5], якому часто не властива адитивність. Об'єм отриманого розчину, частіше за все, не дорівнює загальному об'єму вихідних компонентів. Зменшення об'єму в процесі змішування компонентів отримало назву «контракція». Очевидно, ступінь контракції залежить від хімічного складу. Вперше це явище докладно було вивчено Д.І. Менделєєвим у 1865 p. [14].

Розчини є невизначеними хімічними сполуками, в яких шляхом флуктуацій утворюються кластери одно- або різнорідних молекул. Кластеризація при однакових концентраціях у спиртово-водних розчинах (гліцерин $\epsilon$ триатомним спиртом) збільшується 3 пониженням температури [23].

Модифікація хімічного складу цитоплазми може відбуватися не тільки шляхом додавання проникних і непроникних кріопротекторів, але й шляхом випаровування частини води 3 кріобіологічної системи. Так, О.Т. Ходько та співавт. [36] описали спосіб кріоконсервування меристеми часнику без використання кріопротекторів. Експерименти 3 цією рослинною тканиною проводилися в зимовий період, коли частина води природним чином випаровувалася в процесі зберігання цибулини рослини.

Охолодження біооб'єктів використовується як 3 метою їх консервування, так і руйнування. Наявні теоретичні гіпотези щодо процесів кріодеструкції патологічно змінених тканин у кріохірургії цілком побудовані на уявленні про процеси кристалізації, але вони не враховують можливість здійснення ФП типу рідина-рідина [18].

Виходячи з отриманих даних на практиці можна рекомендувати максимально збільшувати концентрацію клітиної завісі перед охолодженням.

Отже, доцільне подальше вивчення ролі ФП типу рідина-рідина за умов зміни параметрів стану біологічних систем, з метою більш чіткого розуміння фізико-хімічних процесів при кріоконсервуванні та кріодеструкції, що дозволить спростити і прискорити розробку технологічних процесів.

\section{Висновки}

1. Результати оцінки консистенції та поляризаційної мікроскопії в процесі охолодження-нагрівання кріоконсервуючого розчину ЦНДІГПК- $11_{5}$ показали наявність у системі ФП типу рідинарідина, що приводить до утворення висококонцентрованої емульсії, щільність якої нижча за щільність розчину, з якого вона утворена. Ознак кристалізації в досліджуваній системі не виявлено. concentrate of native erythrocytes, its hemolysate, procured by preliminary freezing, and erythrocyte concentrate, supplemented with cryopreservative agent.

Mechanical destruction of glass tubes due to an increase in system volume at PT was observed in cryopreservative-free samples only. The glass tubes, filled with pre-hemolyzed erythrocyte concentrate, were also destroyed during cooling (Fig. 6A). This indicated the identity of phase behaviour of erythrocyte cytoplasm during cooling both inside and outside the cells.

The glass tubes filled with CRIHBT- $11_{5}$ cryopreservative were not destroyed during cooling (Fig. 6B).

When summarized, these results suggest an increased volume of erythrocyte cytoplasm during cooling as a result of LLPT implementation to be the main cause of their hemolysis.

Protective action of cryopreservative agent for erythrocytes is to reduce the surplus increase of their cytoplasm during PT, when it is chemically modified with supplement of cryopreservative solution.

The LLPT is known to be a reverse process as for mixing [40], to which the additivity is not often inherent. The volume of the resulting solution is usually not equal to the total volume of original components. The reduction in volume during component mixing was called contraction. Obviously, the contraction degree depends on chemical composition. For the first time this phenomenon was studied in detail by D.I. Mendeleyev in 1865 [27].

Solutions are unspecified chemical compounds, where the clusters of homo- or heterogeneous molecules are formed by fluctuations. Clustering in alcohol-aqueous solutions (glycerol is a triatomic alcohol) at the same concentrations is increased with temperature reduction [8].

Modification of chemical composition of cytoplasm may occur not only by adding permeable and impermeable cryoprotectants, but if evaporating some water from cryobiological system as well. For example, O.T. Khodko et al. [23] described the cryoprotectant-free technique for garlic meristem cryopreservation. Experiments with this plant tissue were carried out in winter, when some water was naturally evaporated during plant bulb storage.

Cooling of biological objects is used both for their preservation and destruction. Existing theoretical hypotheses about cryodestruction of pathologically altered tissues in cryosurgery are entirely based on ideas about crystallization processes, but they do not take into account a possible implementation of liquid-liquid PT [32]. 
2. Результати спостереження за процесом критичної опалесценції та дані поляризаційної мікроскопії показали, що в процесі охолодженнянагрівання концентрату еритроцитів донорської крові в суміші з кріоконсервантом ЦНДІГПК-11, реалізується критичне ФП типу рідина-рідина за механізмом нуклеації-росту зародків. Ознак кристалізації в досліджуваній системі не встановлено.

3. Методом поляризаційної мікроскопії встановлено кристалізацію надосаду клітинної завісі у процесі охолодження в аналогічних експериментальних умовах.

4. Встановлено, що захисна дія розчину ЦНДІГПК- $11_{5}$ полягає в зменшенні під час ФП ступеня збільшення об'єму цитоплазми еритроцитів, хімічний склад якої змінений шляхом додавання до клітинної зависі розчину захисних сполук.

5. Фізико-хімічні процеси в еритроцитах у процесі кріоконсервування за описаною методикою схожі з такими, що раніше вивчалися в рослинній тканини - меристемі часнику під час переходу до стану холодового анабіозу.

Автор висловлює глибоку подяку співробітничям відділу наноструктурних матеріалів Інституту сичнтиляційних матеріалів НАН України, с. н. с. лабораторії кріопротекторів к. б. н. Пахомовій Ю.С. ма провідній інженериі Чернишенко Л.Г. за технічну допомогу в проведенні експериментів та обробиі одержаних даних.

\section{Література}

1. Берестнева ЗЯ, Каргин ВА. О механизме образования коллоидных частиц. Успехи химии. 1955; (3): 253-9.

2. Боголюбов ДС. Безмембранные органеллы эукариотической клетки: основные понятия и принципы формирования. Цитология. 2019; 63(9): 683-703.

3. Бражкин ВВ. Могут ли стеклообразующие жидкости быть «простыми»? Успехи фризических наук. 2019; 189(6): 66572.

4. Вайнштейн БК, Чернов АА, Шувалов ЛФ, редакторы. Современная кристаллография. В 4-х томах. Москва: Наука; 1979.

5. Вест А. Химия твердого тела. Теория и приложения. Ч. 2. Москва: Мир, 1988. 336 с.

6. Виноград-Финкель ФР, Разумова ЛЛ, Кудряшова СН. Применение рентгенографии для исследования замороженной крови. Биофизика. 1962; 8(2): 229-34.

7. Гельфман МИ, Ковалевич ОВ, Юстратов ВП. Коллоидная химия. Санкт-Петербург: Издательство Лань; 2004. 336 с.

8. Гольцев АМ, Грищенко ВІ, Новак ВЛ, та ін. Кріоконсервування клітин донорської крові та їх довгострокове зберігання у низькотемпературних банках. (Методичні рекомендації). Харків; 2016. 33 с.
Proceeding from our findings, a maximum increase in cell suspension concentration prior to cooling may be recommended in practice.

Thus, further study of contribution of liquid-liquid PT when changing state parameters of biological systems is expedient for a better understanding of physical and chemical processes in cryopreservation and cryodestruction, that would facilitate and accelerate the technology development.

\section{Conclusions}

1. The results on consistency assessment and polarized light microscopy data during coolingwarming of cryopreservative solution CRIHBT-11, showed the presence in the system of the liquid-liquid PT, resulting in formation of highly concentrated emulsion, the density of which was lower vs. the one of solution, from which this emulsion was formed. The studied system exhibited no signs of crystallization.

2. The observation of critical opalescence and data of polarized light microscopy demonstrated the implementation of critical liquid-liquid PT by nucleation and growth mechanism during coolingwarming of donated blood erythrocyte concentrate in a mixture with CRIHBT- $11_{5}$ cryopreservative agent. No signs of crystallization were found in the studied system.

3. Polarized light microscopy detected the crystallization of cell suspension supernatant during cooling under similar experimental conditions.

4. A protective effect of CRIHBT- $11_{5}$ solution was found to reduce the surplus increase in volume of erythrocyte cytoplasm during fluid-liquid PT, the chemical composition of which was changed with supplement of protective compounds to cell suspension.

5. Physical and chemical processes in erythrocytes during cryopreservation by the described technique are similar to those previously studied in plant tissue, namely garlic meristem during entering the cold anabiosis.

The author gratefully acknowledges the colleagues from the Department of Nanostructured Materials of the Institute for Scintillation Materials of the NAS of Ukraine, and Yu.S. Pakhomova, PhD, senior research fellow at the Laboratory of Cryoprotectants, and L.G. Chernyshenko, leading engineer for technical assistance with experiments and data processing.

\section{References}

1. Alberti S, Gladfelter A, Mittang T. Consideration and challenges in studying liquid-liquid phase separation and biomolecular condensates. Cell. 2019; 176 (24): 419-34. 
9. Горелик СС, Дашевский МЯ. Материаловедение полупроводников и диэлектриков. Москва: МИСИС; 2003. 480 с.

10.Жегунов ГФ, Нардид ОА, Стегний БТ. Основы криобиологии и криомедицины. Харьков; 2019. 616 с.

11. Засимчук ВИ, Засимчук ЕЭ, Гаценко АС. Самоорганизация в вязких жидкостях. Металлофизика и новейшие технологии. 2017; (10): 1435-43.

12.Кесслер ЮМ, Петренко ВЕ, Ляшенко АК, и др. Вода: Структура, состояние, сольватация. Москва: Наука; 2003 404 c.

13.Копосов ГД, Тягунин АВ. Калориметрические исследования квазижидкого слоя на поверхности гранул льда. Письма в журнал экспериментальной и теоретической фризики. 2011; (5): 406-9.

14.Менделеев ДИ. Растворы. Издательство АН СССР; 1959. $1163 \mathrm{c}$.

15. Некоз ИА, Гордиенко ЕФ, Кулешова ЛГ, Розанов ЛФ. Особенности гемолиза эритроцитов в водных растворах глицерина. В: Пушкарь НС, редактор. Криоконсервирование клеток и тканей. Харьков: ИПКиК АН УССР; 1989. с. 54-61.

16.Папков СП. Равновесие фраз в системе полимер-растворитель. Москва: Химия; 1981. 272 с.

17.Паташинский ДЗ, Покровский ВЛ. Флуктуационная теория фазовых переходов. Москва: Наука; 1982. 382 с.

18.Прохоров ГГ, Беляев АМ, Прохоров ДГ. Основы клинической криомедицины. Санкт-Петербург-Москва: Книга по требованию; 2017. 608 с.

19.Рыжов ВН, Тареева ЕЕ, Фомин ЮД, Циок ЮН. Сложные фазовые диаграммы систем с изотропными потенциалами: результаты компьютерного моделирования. УФН. 2020; 190(5): 449-73.

20.Саркисов ГН. Структурные модели воды. Успехи фризических наук. 2006; 176(8): 833-45.

21. Фабелинский ИЛ. Молекулярное рассеяние света. Москва: Наука; 1965. 512 с

22.Ходько АТ. Фазовый переход типа жидкость-жидкость как причина гемолиза эритроцитов при охлаждении. В: Рубин АБ, Ризниченко ГЮ, Анашкина АА, редакторы. Сборник научных трудов VI съезда биофизиков России; сентябрь 16-21, 2019, Сочи, Россия. Краснодар; 2019. Т. 2; с. 82-

23.Чєчко Вє, Гоцульский ВЯ. Якісний аналіз кластеризації в водно-спиртових розчинах. Український фрізичний журнал. 2018; 63 (5): 520-5

24.Alberti S, Gladfelter A, Mittang T. Consideration and challenges in studying liquid-liquid phase separation and biomolecular condensates. Cell. 2019; 176 (24): 419-34.

25. Anisimov MA. Critical phenomenons in liquids and liquid crystals. Philadelphia, USA: Gordon\& Breach Science Publishers; 1991. 431 p. USA.

26.Bachler J, Handle P.H., Giovambattista N, Loerting T. Glass polymorphism and liquid-liquid phase transition in aqueous solutions: experiments and computer simulations. Phys Chem 2019; 21 (42): 23238-68.

27.Brangwynne CP. Phase transitions and size scaling of membrane-less organelles. J Cell Biol. 2013; 203: 875-81.

28. Crowe CD, Keating CD. Liquid-liquid phase separation in artificial cells. Interface Focus [Internet]. 2018 [Cited 2019 Jan 8]; 8:20180032. Available from: https://royalsocietypublishing org/doi/pdf/10.1098/rsfs.2018.0032.

29. Cuevas-Velazquez CL, Dinnely JR. Organization out of disorder: liquid-liquid phase separation in plants. Current opinion in plant biology. 2018; 45: 68-74.

30.Davey RJ, Schroeder SLM, ter Horst JH. Nucleation of organic crystals - A molecular perspective. Angew Chem Int Ed. 2013, 52: $2166-79$.

31.Feig JSG, Eisenberg DP, Rabin Y. Polarized scanning cryomacroscopy, part 1: Experimental apparatus and observations of vitrification, crystallization, and photoelasticity effects. Cryobiology. 2016; 73: 261-71.
2. Anisimov MA. Critical phenomenons in liquids and liquid crystals. Philadelphia, USA: Gordon \& Breach Science Publishers: 1991. $431 \mathrm{p}$.

3. Bachler J, Handle PH, Giovambattista N, Loerting T. Glass polymorphism and liquid-liquid phase transition in aqueous solutions: experiments and computer simulations. Phys Chem Chem Phys. 2019; 21 (42): 23238-68.

4. Berestneva ZYa, Kargin VA. [On the mechanism of formation of colloidal particles]. Uspekhi Khimii. 1955; (3): 253-9. Russian.

5. Bogolyubov DS. [Membrane-less organelles of the eukaryotic cell: basic concepts and principles of formation]. Cytology. 2019; 63(9): 683-703. Russian.

6. Brangwynne CP. Phase transitions and size scaling of membrane-less organelles. J Cell Biol. 2013; 203: 875-81.

7. Brazhkin VV. [Can glass-forming liquids be "simple?"]. Uspekhi Fizicheskikh Nauk 2019; 189; (6): 665-72. Russian.

8. Chechko VYe, Gotsulskyi VYa. [Qualitative analysis of clustering in aqueous alcohol solutions]. Ukrainian Journal of Physics. 2018; 63; (6): 520-5. Ukrainian.

9. Crowe CD, Keating CD. Liquid-liquid phase separation in artificial cells. Interface Focus [Internet]. 2018 [Cited 2019 Jan 8]; 8:20180032. Available from: https://royalsocietypublishing. org/doi/pdf/10.1098/rsfs.2018.0032.

10.Cuevas-Velazquez CL, Dinnely JR. Organization out of disorder: liquid-liquid phase separation in plants. Curr Opin Plant Biol. 2018; 45: 68-74

11. Davey RJ, Schroeder SLM, ter Horst JH. Nucleation of organic crystals - A molecular perspective. Angew Chem Int Ed. 2013; 52: 2166-79. DOI: 10.1002/anie. 201204824

12. Fabelinskii IL. [Molecular dissipation of light]. Moscow: Nauka; 1965. 512 p. Russian.

13.Feig JSG, Eisenberg DP, Rabin Y. Polarized scanning cryomacroscopy, part 1: Experimental apparatus and observations of vitrification, crystallization, and photoelasticity effects. Cryobiology. 2016; 73: 261-71.

14.Fuller BJ, Lane N, Benson EE, editors. Life in the frozen state. Boca Raton, USA: CRC Press, 2004. 663p.

15.Gelfman MI, Kovalevich OV, Yustratov VP, at al. [Colloid chemistry]. St. Petersburg: Lan'; 2004. 336 p. Russian.

16. Goltsev AN, Grischenko VI, Novak VL, at al. [Cryopreservation of donor blood cells and their long-time storage at low temperature banks]. (Guidelines). Kharkiv: 2016. 33 p. Ukrainian.

17.Gorelik SS, Dashevsky MYa. [Materials science of semiconductors and dielectrics]. Moscow: Nauka; 2003. 404 p. Russian.

18. Holmberg K, Jönsson B, Kronberg B, Lindman B. Surfactants and polymers in aqueous solutions. Chichester: John Wiley \& Sons, 2002. 562p.

19. Hyman AA, Weber CA, Jülicher F. Liquid-liquid phase separation in biology. Annu Rev Cell Dev Biol. 2014; 30: 39-58.

20.Keating CD. Aqueous phase separation as a possible route to compartmentalization of biological molecules. Acc Chem Res 2012; 45: 2114-24.

21. Kessler UM, Petrenko VE, Liaschenko AK. [Water: structure, condition, solvation] Moscow: Nauka; 2003. 404 p. Russian.

22. Khodko AT. [Liquid-liquid phase transition as a cause of erythrocyte hemolysis during cooling]. In: Rubin $A B$, Riznichenko GYu, Anashkina AA, responsible editors. The materials of the VI Congress of Biophysicists of Russia; September 1621, 2019, Sochi, Russia. Krasnodar; 2019; Vol. 2; p. 82-3.

23. Khodko AT, Lysak YuS. Physical and chemical processes in embryonic plant tissue during the transition to the state of cold anabiosis and storage at liquid nitrogen temperature. Low Temperature Physics. 2017; 43: 1196-200.

24.Koposov GP, Tyagunin AV. [Calorimetric studies of quasi-liquid layer on the surfaces of ice granules]. JETP letters. 2011; (5): 406-9. Russian.

25.Lee CF, Brangwynne CP, Gharakhani J, et al. Spatial organization of the cell cytoplasm by position-dependent phase separation. Phys Rev Lett. [Internet]. 2013 [Cited 2019 Jan 
32. Fuller BJ, Lane N, Benson EE, editors. Life in the frozen state. Boca Raton, USA: CRC Press, 2004. $663 \mathrm{p}$.

33. Holmberg K, Jönsson B, Kronberg B, Lindman B. Surfactants and polimers in aqeoues solutions. Chichester: John Wiley \& Sons, 2002. $562 \mathrm{p}$.

34. Hyman AA, Weber CA, Jülicher F. Liquid-liquid phase separation in biology. Annu Rev Cell Dev Biol. 2014; 30: 39-58.

35. Keating CD. Aqueous phase separation as a possible route to compartmentalization of biological molecules. Accounts of Chemical Restach. 2012; 45: 2114-24.

36. Khodko AT, Lysak YuS. Physicochemical processes in embryonic plant tissue during the transition to the state of cold anabiosis and storadge at liquid nitrogen temperature. Low Temperature Physics. 2017; 43: 1196-200.

37.Lee CF, Brangwynne CP, Gharakhani J, et al. Spatial organization of the cell cytoplasm by position-dependent phase separation. Physical review letters. [Internet]. 2013 [Cited 2019 Jan 8]; 111,088101. Available from: https://journals.aps. org/prl/pdf/10.1103/PhysRevLett.111.088101.

38. Ma S. Modern theory of critical phenomena. West view press, 2000. $558 p$

39. Mollison PL, Sloviter HA. Successful transfusion of previously frozen human red cells. Lancet. 1951; 261 (11): 862 4.

40.Style RW, Sai T, Fanelli N, et al. Liquid-liquid phase separation in an elastic network. PhysRev [Internet]. 2018 [Cited 2019 Jan 8]; 8(1):011028. Available from: https://journals.aps. org/prx/pdf/10.1103/PhysRevX.8.011028.

41.Tropin TV, Schmelzer JWP, Aksenov VL. Modern aspects of the kinetic theory of glass transition. Phys. Usp. 2016; 59: 4266.

42. Veesler S, Revalor E, Bottini O, Hoff C. Crystallization in the presence of liquid-liquid phase separation. Organic process research \& development. 2006; 10: 841-5.

43. Wowk B. Thermodynamic aspects of vitrification. Cryobiology 2010; 60 (5): 11-22.
8]; 111:088101. Available from: https://journals.aps.org/prl/ pdf/10.1103/PhysRevLett.111.088101.

26. Ma S. Modern theory of critical phenomena. Westview Press, 2000. $558 \mathrm{p}$.

27.Mendeleyev DI. [Solutions]. Moscow: Publishing House of USSR Academy of Sciences; 1959. 1163 p. Russian.

28. Mollison PL, Sloviter HA. Successful transfusion of previously frozen human red cells. Lancet. 1951; 261 (11): 862-4.

29. Nekoz IA, Gordiyenko YeA, Kuleshova LG, et al. [Features of hemolysis of erythrocytes in aqueous solutions of glycerol]. In: Pushkar NS, editor. [Cryopreservation of cells and tissues]. Kharkiv: IPCC AS of UkSSR; 1989. p. 54-61. Russian

30.Papkov SP. [The phase equilibrium in polymer-solvent system] Moscow: Khimiya; 1981. 272 p. Russian.

31.Patashinskiy AZ, Pokrovskiy VL. [Fluctuation theory of phase transitions]. Moscow: Nauka; 1982. 382 p. Russian.

32.Prokhorov GG, Belyayev AM, Prokhorov DG [The basis of clinical cryomedicine]. St. Peterburg-Moscow: Kniga Po Trebovaniyu; 2017.608 c. Russian.

33.Ryzhov VN, Tareyeva EE, Fomin YuD, Tsiok EN. [Complex phase diagrams of systems with isotropic potentials: results of computer simulations]. Uspekhi Fizicheskikh Nauk. 2020; 190(5): 449-73. Russian.

34.Sarkisov GN. [Structural models of water]. Uspekhi Fizicheskikh Nauk 2006; 176(8): 833-45. Russian.

35.Style RW, Sai T, Fanelli N, et al. Liquid-liquid phase separation in an elastic network. Phys Rev X [Internet]. 2018 [Cited 2019 Jan 8]; 8(1):011028. Available from: https://journals. aps.org/prx/pdf/10.1103/PhysRevX.8.011028

36. Tropin TV, Schmelzer JWP, Aksenov VL. Modern aspects of the kinetic theory of glass transition. Phys Usp. 2016; 59: 42-66.

37. Vainshtein BK, Chernov AA, Shuvalov LF, editors. [The modern crystallography]. Moscow: Nauka; 1979. 4 vol. Russian.

38. Veesler S, Revalor E, Bottini O, Hoff C. Crystallization in the presence of liquid-liquid phase separation. Org Process Res Dev. 2006; 10: 841-5.

39. Vinograd-Finkel FR, Razumova LL, Kudryashova SN. [The use of radiography to study frozen blood]. Biofizika. 1960; 5(2): 229-34. Russian.

40.West AR. [Solid state chemistry. Theory and applications]. Part 2. Moscow: Mir; 1988. 336 p. Russian.

41. Wowk B. Thermodynamic aspects of vitrification. Cryobiology. 2010; 60 (5): 11-22.

42.Zasimchuk VI, Zasimchuk YeE, Gatsenko AS. [Self-organisation in viscous liquids]. Metallofizika I Noveishie Tekhnologii. 2017; (10): 1435-43. Russian.

43.Zhegunov GF, Nardid OA, Stegniy BT. [The basis of cryobiology and cryomedicine]. Kharkiv: 2019. 616 p. Russian. 